\title{
Using Story Frame Approach to Increase Students' Reading Comprehension at Senior High School
}

\author{
Putri Nurlia $^{1}$, Sri Ramadhona ${ }^{2 凶}$, Sinta Dwi Devita ${ }^{2}$ \\ ${ }^{1,2}$ English Department, Tarbiyah and Teacher Training Faculty, IAIN Langsa,Aceh, Indonesia \\ 凶 email: ramadhona2301@gmail.com
}

Received:

24 December

2020

Revised:

13 January

2021

Accepted:

25 January

2021

\begin{abstract}
Using the Story Structure Approach to Increase Students. Reading Comprehension at the tenth grade of SMAN 2 Kejuruan Muda. This research was conducted on the Story Frame technique to improve students' awareness of reading. It was done in the Senior High School. This research used a quantitative approach with an experimental class and a control class needed. As the sample, there were 28 students in each experimental and control classes. Test and observation were used in the data collection technique. Then the result of the test will score by using analytic score and the researchers used "t-test" formula to calculated the data by comparing students' pre-test and post-test. This study found that students reading posttest score in experimental class using story frame strategy had a higher score of 76,67 higher than the student control class and a score post-test of 67,62 , based on the formula, the difference in control class learning without Story Frame strategy. In addition, the Story Frame technique has made their reading comprehension more important. Based on these results, it concluded that the Story Frame technique could increase students' reading comprehension. Thus the hyphothesis was approved by the research method.
\end{abstract}

Keywords: reading comprehension; story frame; strategy

\section{INTRODUCTION}

English is one of an interactional language which has an important role in the world. In some countries the power language is the official language which is used for government education commerce and international communication. In Indonesia English is a foreign language that is taught from elementary school to university. English is a foreign language used a medium of instruction at school, many students think that English is the most difficult subject.

In Indonesia English is taught as a subject material that should be learned in elementary school, junior high school, senior high school, and university students. Learning English means learning language components and language skills. Baker (2011) says that grammar, pronunciation, vocabulary, and spelling are included in language components.

Meanwhile, language skills cover reading, listening, writing, and speaking.Among those language skills, reading is one of the important skills in learning English. According to Risdianto (2012), reading involves similar cognitive processes. Reading is the construction of meaning through relationships of parts from the text and prior knowledge. When the students read, they make predictions about text, they are 
not simply reading for meaning but is focused on the events based their interpretation. In other words, the readers make predictions, construct meaning and struggle to understand the texts.

It means that reading is an important part that needs to be developed. By reading, the students get much information and knowledge. Moreover, they can improve their ability in English. master the standard competence in reading activity. The standard competence in reading activity is to understand the meaning of a short simple essay form reading text to interact in environment around.

Based on the standard competence above, the students should read the text, understand the meaning and answer the questions depending on the text given.Many students of the tenth grade SMAN 2 Kejuruan Muda, get a lot of difficulties in order to answer the questions, find the main idea of the text, and also get the information of text because they do not understand what the text tells about. Because of the problems that students face in learning reading texts, the teachers should have an appropriate strategy in teaching reading skill for students, especially in teaching narrative text. By using an appropriate strategy, students are expected to comprehend the narrative texts better.

According to Oja (1996) repeated readings, story retellings, dramatics reenactments, and story frames are the strategies that allow students to become more aware of stories and more familiar about the structure, especially narrative texts. Dealing with the cases of the tenth grade students above, the researcher assumes and predicts the Story Frames strategy may become an appropriate strategy that the teachers can use to overcome those problems.

Based on the background above, the researcher would conduct experimental research by applying Story Frames as an alternative strategy to increase students' ability in reading, especially narrative text. The researcher is interested in carrying the research entitled "Using Story Frame Approach to Increase Students Reading Comprehension at Senior High School".

\section{METHOD}

This study used quantitative approach. It is because the analysis of the stressed on the numerical data that processed with statistically. The study researcher used the experimental research as the design of this research. Experiment were carried out in order to explore the strength of the relationship between variable. A variable, as the term itself suggests, is anything which does not remain constant (Nunan, 1992). There are two classes in this model, experimental and control class.

In this research experimental class received a treatment that was taught by used story frame strategy, in control class the writer used three phase reading. story frame strategy and students' reading. This research focused on comprehension. The result of the analysis was interpreted to find out the used of story frame strategy in improved students reading comprehension.

Population was the whole total of anylitical unit which the characteristics was given still be preassumed (Singarimbun \& Efendi, S, 1995). In the research that was 
conducted to students at the first grade SMAN 2 Kejuruan Muda in the academic year 2019/2020 that consists of several classes with a particular amount of Story Frame.

Meanwhile, sample is a partial part of total population, which is taken from part of population, in such a way to represented the whole total of population itself (Soewadji, Y, 2012). The sample was taken as much as $20 \%$ from the total population, because the total population itself was exceeding a hundred/ 100 (Arikunto, 2006). To derive the particular representative sample, so the sample technique that was used is the Proportional Random Sampling, in which the sample was taken from a populations that has already been categorized with a stable result or proportional. This technique used the populations has already been categorized into some clasees with the same exact amount (Arikunto, 2006). The amount of the sample in this research was some particular amount of students, which is $20 \%$ from each classes. There were 28 students in each experimental and control classes.

In this research, the collection data technique used test as instrument study. Test was use to measure reading comprehension of the subject being researched. Instrument in form of test can be used to find out the basic competence and achievement (Ibrahim, \& Sudjana, N). Test was a set of question and exercise used to measure the achievement or capacity of the individual or group in order to discover how students reading comprehension. Test was use to measure the person's competence and to achieve the objective. This method was used to get subjects' score in reading comprehension. The form of test which was used completion.

Besides doing the test, the writer would did a classroom observation. Observation was more then just looking and seeing. The task of observation was to be able to represent a social scene in a way was recognizable to the actors involved, it was considered valid and a true representation of students reading comprehension. In this observation, the researcher involved with the students activities of students who are in observed being use as a source of research data, and the writer used observation checklist in collecting the data.

The writers used a quantitative data was related to numerals and it was analyzed by statistics. The researcher used "t-test" formula to calculated the data by comparing students' pre-test and post-test.

The researcher tested the data by using following steps in data to respond the objective of the research. 
1. Doing the test in both group, experimental group and control group that has been taught by using story frame and the control group that hasn't taught by story frame.

2. The result of the test will score by using analytic score.

3. Determining the mean scores of each those two group

\section{FINDING AND DISCUSSION}

\section{Findings}

In this research, the researcher used a quanti-experimental research to ascertain the increasing of using story frame toward students reading ascertain the comprehension at the tenth grade students of SMAN 2 Kejuruan Muda in academic year 2019/2020. The data of students' achievement was divided into two kinds, namely the data in experiment class and the data in control class, which. The result of the test presented on the table below:

Table 1. Frequency distribution table of pre-test in experimental class

\begin{tabular}{lll}
\hline NO & Number of score & Total students \\
1 & $50-60$ & 25 \\
2 & $61-70$ & 3 \\
3 & $71-80$ & 0 \\
4 & $81-90$ & 0 \\
5 & $91-100$ & 0 \\
6 & Total & 28 students \\
\hline
\end{tabular}

Table 2. Frequency distribution table of post-test in experimental class

\begin{tabular}{lll}
\hline No & Number of score & Total students \\
1 & $50-60$ & - \\
2 & $61-70$ & - \\
3 & $71-80$ & 27 \\
4 & $81-90$ & 1 \\
5 & $91-100$ & 0 \\
6 & Total & 28 students \\
\hline
\end{tabular}

As mentioned in the table, it can be clarified that the mean score of pretest in experiment class is 57.71, while the mean score of post-test was 76.67. The total gained score in this class was 528. It can be known that there was significant difference in the pre-test and post-test.

Table 3. Frequency distribution table of pre-test in control class

\begin{tabular}{lll}
\hline No & Number of score & Total Students \\
1 & $50-60$ & 22 \\
2 & $61-70$ & 5 \\
3 & $71-80$ & 0 \\
4 & $81-90$ & 0 \\
5 & $91-100$ & 0 \\
6 & Total & 27 students \\
\hline
\end{tabular}

Table 4. Frequency distribution table of post-test in control class 


\begin{tabular}{lll}
\hline No & Number of score & Total students \\
1 & $50-60$ & 2 \\
2 & $61-70$ & 24 \\
3 & $71-80$ & 1 \\
4 & $81-90$ & 0 \\
5 & $91-100$ & 0 \\
6 & Total & 27 students \\
\hline
\end{tabular}

The table 3 and 4 above informed that the mean score of pre-test in control class is 64.85 , while the mean score of post-test there is 67.62 . The total gained score is 230 (see appendix 2) From the tables presented above the writer can explain that in pre-test the experiment class had the lower score than the control class, however in post-test the experiment class using story frame had the higher score than the control class without using story frame. As mentioned before, in analyzing the data from the result of pretest and post-test.

\section{Discussion}

After conducted the research, the researcher found that there was significant improvements of students' reading comprehension on narrative texts through Story Frames to the tenth grade students of SMAN 2 Kejuruan Muda. The researcher got the data from the results of the tests of experimental class and control class. Moreover, from the data, the researcher calculated the t-test to measure the improvements of the research. The result of the calculation demonstrated in the table below:

From the table above, the researcher found that the result of pre-test in cycle experimental class was 57.71 While, the result of pre-test in control class was 64.85 . then, the result post- test of experimental class was 76.67 and post- test in control class was 67.62. It means that, there was an improvement of the result of pre-test and post test in the group of class. While, the result of gained score in experimental class was 18.85 and the gained score of control class was 8.51. Therefore, from the table above, it showed the result of the calculation of t-test of the both class. The calculation of t-test calculated to prove the improvement of students reading comprehension on narrative texts to the eighth grade students of SMAN 2 Kejuruan Muda. The researcher compared the t-test and the t-table to measure the improvement. The t-table with significance level o and $\mathrm{N}-1=28$ was 2.01 . The result of t-test in the both pre- test and post- Test showed that, there was significant improvement of students reading. Comprehension on narrative texts through story frames to the tenth grade students of SMAN 2 Kejuruan Muda in the academic year of 2019/2020.

As mention in the previous chapter, although the Story Frames strategy have several weaknesses, the strength of this strategy is more beneficial for both sfuudents. The data analysis shows that the Story Frames became an appropriate strategy for teachers to teach narrative reading texts. Therefore, Story Frames ctrategv helps students to comprehend their reading comprehension especially narrative texts. From the data, the researcher find that the use of Story Frames successfully enhances students' reading comprehension on narrative texts of the tenth grade students of SMAN 2 Kejuruan Muda in the academic year of 2019/2020. 
From the discussion above above, The researcher compare the paper from some students and they shows that before given story frame strategy they seldom use context clue to help them better understanding the reading comprehension, and they also seldom guess uncommon words they found in the texts. Besides that, they also use a clue given in the reading, like according to the hypothesis test result analysis it can be conclude that the improving difference on the test result from the experiment class is also followed by the higher reading strategy level, which is from low level to the medium level.

\section{CONCLUSION}

From the research findings and discussion, it is proven that teaching with using story frame strategy has improved the ability of students reading comprehension. Based on the research problem of study the researcher found that students more improved in reading comprehension by using story frame strategyy. in this research the researcher implemented story frame strategy after pre- test activity and students had low score in pre- test activity many, many students difficulties in understanding reading comprehension. The students Mean in pre- test was 57.71 and after give treatment students score was higher than pre- test was 76.67. Then, in control class the researcher not implemented story frame strategy. The score of pre- test was 64.85 and post- test score was 67.62. it can be conclude that story frame strategy can improve students reading comprehension especially in narrative text.

\section{REFERENCES}

Arikunto. (2006). Prosedur penelitian. PT Rineka Cipta.

Baker, C. (2011). Foundation of bilingual education dan bilingualism. Multi Lingual Matters.

Bamberger, R. (1975). Promoting the reading habit. Pers Unesco: Unesco Blachhowic.

Ibrahim, \& Sudjana, N. (n.d). Penelitian dan pendekatan. LP3ES.

Nunan, D. (2003). Practical English language teaching. Mc Grawhill Publishing.

Oja, L.A. (1996). (n.d). Using story frames to develop reading comprehension. Journal of adolescent and adult literacy. http://www.jstor.org/stable/40016749, 1996.2.

Risdianto, F. (2012). Effective and eficient reading. Rustam Publishing.

Singarimbun \& Efendi, S. (1995). Metode penelitian dan survey. PT Pustaka.

Soewadji, Y. (2012). Pengantar metode penelitian. Mitra Wacana Media. 